\title{
The irruption of Afro-descendants in diversity politics: the case of Arica in northern Chile
}

\section{Francisca De la Maza \& Luis Eugenio Campos}

To cite this article: Francisca De la Maza \& Luis Eugenio Campos (2020): The irruption of Afro-descendants in diversity politics: the case of Arica in northern Chile, Identities, DOI: 10.1080/1070289X.2020.1813458

To link to this article: https://doi.org/10.1080/1070289X.2020.1813458

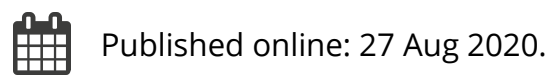

Submit your article to this journal $₫$

Q View related articles ๘

View Crossmark data ¿ 


\title{
The irruption of Afro-descendants in diversity politics: the case of Arica in northern Chile
}

\author{
Francisca De la Maza a and Luis Eugenio Campos ${ }^{\mathrm{b}}$ \\ aPontificia Universidad Católica de Chile-Center for Intercultural and Indigenous Research- \\ CIIR, Santiago, Chile; bUniversidad Academia de Humanismo Cristiano-Center for Intercultural \\ and Indigenous Research-CIIR, Santiago, Chile
}

\begin{abstract}
This paper analyses the irruption of Afro-descendants in the sphere of local and national public policies as aresult of their demand for political recognition. Starting in 2000, an Afro-descendant movement developed, positioning itself locally and nationally and obtaining political recognition in 2019 under Law $\mathrm{N}^{\circ}$ 21.151. Incorporating a'new diversity' in the design and implementation of public policies as distinct from the indigenous policies that had been implemented for more than 25 years. The paper analyses different levels of state action, relations with other diversities in the implementation of targeted policies (particularly indigenous policies) and the process of Afro-descendant recognition itself. This case shows the difficulties in broadening the social and state vision of cultural diversity and how these are reflected in disputes about the legitimacy of being the 'original' peoples as well as for spaces of power and state resources.
\end{abstract}

ARTICLE HISTORY Received 29 December 2016; Accepted 17 August 2020

KEYWORDS Multicultural policies; recognition; Afro-descendants; indigenous peoples; Arica; Chile

\section{Introduction}

Afro-descendants in Chile obtained legal recognition on 16 April 2019 with the approval of Law $N^{\circ} 21.151$. Their recognition was the result of the struggle of Afro-descendant organisations in the Arica y Parinacota Region, in the far north of Chile, which had been gaining visibility since $2000 .{ }^{1}$ The Afrodescendants have their origin in the slave trade and have lived in the region since Colonial times. However, the prevailing view in Chile is that the country does not have an Afro-descendant population or, if it exists, it is a historical remnant of the time before the War of the Pacific (1879-1883) when the area formed part of Peru. 
The process of obtaining approval of Law $\mathrm{N}^{\circ} 21.151$ was long and difficult. During it, this group, whose existence had been denied, gradually gained space at both the regional and national levels. As a result, 'Afro-descendant' matters became a focus of public policy, creating tensions and serving as a learning process for the state and regional society in general. Public policies on cultural diversity, which had been in place for more than 25 years, and had acquired legitimacy and become institutionalised, but targeted only indigenous peoples (at the national and regional levels).

Given this context, this paper analyses the case of Afro-descendants as a focus of public policy, examining the problems that arose in incorporating this 'new' diversity in line with their progressive recognition at the regional and national levels. The analysis reveals the different forms of construction of identity and the disputes for spaces of power that occurred at the municipal, regional and national levels.

Around the world, different public policies have incorporated cultural diversity in their design. For over 30 years, these multicultural policies (Kymlicka 1995, 2011), recognition politics (Taylor 1993) or indigeneity politics (Maaka and Fleras 2005), to mention a few of their names, have sought to foster respect for and the inclusion of the ethnic and cultural identities that make up the different national states. These policies, which are also referred to as post-multicultural (Vertovec 2010; Gozdecka, Ercan, and Kmak 2014; Postero 2007), have developed in different situations and have numerous expressions depending on their context. They have resulted in transformations in the way countries and their citizens function politically (Kymlicka 2011) and, to some extent, in relation to the demands and rights of indigenous peoples, migrants and other identities.

In countries that receive a large inflow of migrants as in Europe and North America, multicultural policies have focused on addressing this type of diversity (Vertovec 2001; Citrin, Levy, and Wright 2014; Kymlicka 2011). In Latin America, on the other hand, they have focused mostly on the existence and pre-existence of indigenous peoples, resulting in different reforms of the state (Stavenhagen 2002; Aylwin 2014; Assies, Van Der Haar, and Hoekema. 2002; Sieder 2002; Giraudo 2007). Specific policies on Afro-descendants have also been introduced as in Colombia, Ecuador and Bolivia (Echeverri-Pineda 2018; Duconge and Guizardi 2014) and on migrants in terms of recognition of their rights (García and Gainza 2014, Chiarello 2013). There are also other emblematic cases such as the United Kingdom and other European countries, Canada and New Zealand (Maaka and Fleras 2005), which have deployed policies on migrants as well as the indigenous population, and Australia, with its Aboriginal population (Kowal 2008). In some countries in Southeast Asia and in the United States, economic and indigenous migration overlap and policies, albeit not necessarily incorporating the ethnic variable, seek primarily to address the social and economic vulnerability that is accentuated by the 
cultural and political differences of the migrant groups (Holmes 2013; Constable 2014).

Countries have had to foster recognition of cultural diversity against a background of a history that tends to be rooted in the idea of a single national and cultural identity. In Latin America, recognition or multicultural policies have focused on indigenous peoples and this has been the case in Chile since the restoration of democracy in 1990 while the expansion of the discussion to other diversities has been more recent. Although, after a process of almost 20 years, Afro-descendants achieved legal recognition and the gradual introduction of differentiated local policies, policies for groups such as migrants, who are in a situation of even greater social and political vulnerability, have been almost entirely absent. In the case of migrants, their number and growing presence in different regions indicate that this should be addressed as a national issue but the response so far has been confined to specific problems. The emergence of these multiple identities and demands calls for new ways of designing and implementing public policies for these subjects, who have experienced the same historical processes of exclusion as indigenous peoples and are demanding recognition and specific public policies, but have so far received little attention from the institutional framework.

By examining the case of Afro-descendants, this paper contributes to the understanding of these relationships in a context of multiple identities (or the emergence of multiple identities). The question that guides this paper is: How is a national and local public policy, geared to a 'new' diversity in the form of the emergence of Afro-descendants, developed? How does this recognition create tension with other already institutionalised policies on cultural diversity (indigenous policies) and the associated communities?

Regarding the research methodology, the results presented here are part of a larger study being carried out in five territories in Chile in a bid to understand the different ways in which the state is built, is responded to and influences the everyday practices of the inhabitants of the teritory in different contexts of cultural diversity. In particular, this paper uses an ethnographic approach to study the Arica municipal district where one or both authors carried out fieldwork between 2013 and 2016, visiting the area for 15 days or more at least four times a year. Over 60 interviews were conducted with regional and municipal public officials and with local leaders. State practices were observed in technical working groups with migrants and Afrodescendants as well as by participating in outreach activities such as the launch of an Afro-descendant gastronomy and identity project and by accompanying municipal officials on their fieldwork.

Further periodic visits were made to the area between 2017 and 2019 to participate in seminars and meetings with Afro-descendant leaders linked to the recognition process and to participate in various discussions about the bill 
that concluded with Afro-descendant recognition. From the beginning, the fieldwork was carried out in collaboration with the municipal government and local representatives and included participatory actions and instances of communication between local counterparts and the researchers. The research team held meetings with municipal authorities and meetings and work sessions took place with the leaders of Afro-descendant and indigenous organisations.

As part of the collaborative work, a Sociocultural and Historical Characterisation Study for Afro-descendant Recognition was carried out in conjunction with the municipal office for Afro-descendants and with Afrodescendant organisations. This was led by one of the authors of this paper and also involved ten undergraduate students who wrote theses related to this characterisation. This survey played an important role in legislative discussion of the recognition bill.

Under an agreement with the municipal government, a short course (15 hours) on intercultural skills was taught for municipal officials, seeking to strengthen their awareness and understanding of the territory's cultural diversity and their role in public action. The course, which was attended by officials from different departments, addressed issues related to their role in the municipal government and in relation to the local population. This training included applied activities such as 're-creations' of everyday state practices and reflections about discrimination and prejudices at the local level. The team's participation in these processes was key for understanding the tensions generated within the state apparatus as a result of these recent mechanisms of recognition of cultural diversity. Below, we will return to these two actions (the Sociocultural and Historical Characterisation for Adodescendant recognition and the short course) in order to deepen and illustrate our argument. ${ }^{2}$

\section{Analytical approach and the Chilean context}

Public policies are conceived as a reflection of a vision and project of society promoted by the state through concrete actions that affect the daily lives of citizens who, in turn, have the capacity to respond to and influence them. Through the study of public policies, it is possible to focus on connections between actors, discourses and practices and explore details of daily life as part of a broad social and political process of transformation (Wright 2011). In the specific case of recognition of cultural diversity, it is possible to analyse the construction of the state and citizenship in a context of identitary disputes in specific territories in which certain groups, whose existence is often denied or rendered invisible, demand to be recognised in their diversity as subjects of law.

In Latin America, public policies for Afro-descendants have varied depending on whether the country has a large number of them, as in Brazil, or 
whether their symbolic weight means that they have been visible for many years as in Uruguay and Peru (Campos 2017). In some countries such as Mexico, Colombia and Bolivia, the legal frameworks that would permit their inclusion have been widely discussed, mostly in relation to indigenous recognition (Wade 2005; Restrepo 2013).

In other countries like Chile, Argentina and, to a lesser extent, Ecuador, their existence has been denied as part of an ideology of indigenous-Spanish miscegenation and 'whitening'. Given that their recognition is recent or still absent in these countries, public policies have been non-existent, ambiguous and contradictory. Some studies (Lipschutz 1944; Telles 2014; Campos 2017) have addressed the Afro-descendant issue from the standpoint of pigmentocracy, which emphasises the policies of racial and cultural segregation implemented in the Americas since Colonial times. Even Afro-descendants themselves in Chile have referred to structural racism to characterise their ethnic and racial relations in the region (Báez 2010; Salgado 2013).

This is in contrast to policies in Latin America for indigenous peoples. Since the formation of the region's nation states, these policies have been formulated and transformed, ranging from more assimilationist to rights-based approaches. Today, the concept of interculturality is widely accepted and applied at different levels of public policy for indigenous peoples, such as intercultural education and healthcare. The broad use of the concept has hindered critical analysis of the implications of these intercultural policies since, instead of transforming the relations of domination of one group over another, they have often reproduced the deep structures of power relations. This explains why some authors criticise this concept as a new form of domination and reproduction, under another name, of the same forms of state action (Boccara and Bolados 2010; Pozo 2014).

Chile was a latecomer to multicultural policies for indigenous peoples. At present, they are not recognised in the Constitution and policies have their origin in Indigenous Law N ${ }^{\circ} 19.253$, which came into force in 1993. As in other Latin American countries, the concept of intercultural policies is widely accepted but they are, in practice, indigenous policies since they target primarily the indigenous population. ${ }^{3}$ This has led some indigenous sectors to question these policies on the grounds that they should target all the population in an 'interculturality for all', not merely indigenous people but society as a whole. In this sense, the concept of interculturality for all could incorporate other diversities, such as Afro-descendants. However, among both indigenous and non-indigenous officials, a representation and appropriation of interculturality as only for indigenous people persists.

It is important to mention here the case of migrants, who have become visible in Chile in recent years, creating great tension in the construction of public policies. In contrast to indigenous recognition politics, which call into question the nation state as an ideological project based on pre-existing 
peoples, or the case of Afro-descendants, who demand recognition on the grounds of their presence in the country since Colonial times, migration as a political phenomenon is more a matter of managing these new groups through existing public policies and implementing others, which are often flawed and contradictory. Chile's migration policies are based on Decree Law 1094, introduced in 1975 by the military dictatorship, and, despite some subsequent modifications, they take a policing and control approach that does not address the changes that have occurred in migration in recent decades (Guizardi, Pérez et al. 2015).

This background helps to understand the effects of the Afro-descendant recognition process in Chile. National identity has historically been shaped on the basis of a pigmentocratic Europeanising matrix (Lipschutz 1944; Telles 2014; Campos 2017) that excluded both indigenous peoples and Afrodescendants. Although dating back to the European invasion, this approach was consolidated with the birth of the current national states and, although the responses of both indigenous peoples and Afro-descendants were always present, it was not until the democratisation processes of the 1980s that they began to be truly considered as subjects of rights in Latin American countries. In parallel to these internal processes, great transformations were occurring internationally as reflected in the International Labour Organisation's Convention 169 on Indigenous and Tribal Peoples, published in 1989 (ratified by Chile in 2008 and implemented in 2009), and, in 2007, the UN Declaration on the Rights of Indigenous Peoples. All these changes opened the way to recognition of the differential rights of indigenous peoples which, in turn, had an impact on the resurgence of identities that until then had been invisibilised or strategically hidden from the majority of the population.

As a result, many previously unrecognised indigenous peoples embarked on processes of ethnic re-emergence, re-ethnicisation or, as it has been more widely understood, ethnogenesis. Ethnogenesis is understood here as the process through which, in the face of changes in recognition politics, previously unrecognised identities reappear and demand their rights as living indigenous peoples. As a broad concept, ethnogenesis includes processes of re-ethnification and ethnification (generally driven by external actors) and indigenous re-emergence and emergence (due to the historical and political circumstances specific to a group). Over the past 20 years, peoples thought to have been extinct have reappeared in Latin America such as the Diaguita and Chango peoples in Chile, the Diaguita, Huarpe and Comechingon peoples in Argentina and the Charrua people in Uruguay.

This same context also fostered the strong reappearance of Afrodescendant identitary processes in countries that had, until recently, denied their Afro origins. This was the case in Uruguay, Argentina and, most recently, Chile. The case of Chile, therefore, points to a process of ethnogenesis among Afro-descendants who, since 2000, had been gaining visibility and 
demanding their place on the recognition politics agenda, both in the Arica Region and at the national level.

\section{The Afro-descendants of Arica: national positioning and disputes}

The historical and current characteristics of the Arica y Parinacota Region and the Arica municipal district indicate that they are a space of multiple diversity or super-diversity in the terms of Vertovec (2007). The area's Andean tradition, with a mainly Aymara and Quechua indigenous population, is shared by neighbouring countries. Together with the proximity of border crossings, this means a high level of movement of Chileans, Peruvians and Bolivians, many of them indigenous, giving the area its diverse composition.

According to the 2017 National Census, the Arica y Parinacota Region had 226,068 inhabitants of whom $98 \%$ were living in the Arica municipal district. In the Census, $35.7 \%$ of the regional population self-identified as indigenous and, out of these, $75.4 \%$ as Aymara. ${ }^{4}$ There is, in addition, a foreign migrant population that has increased and, according to the Census, accounted for $6.2 \%$ of the regional population (Rojas and Bueno. 2014). It comprises principally Peruvians, Bolivians, Colombians and Ecuadoreans. ${ }^{5}$

In response to a lack of information about the Afro-descendant population and its importance for their national and regional recognition, Afrodescendant organisations had been calling since 2008 for the incorporation of a question in the Census. In 2013, in a partial response, the National Statistics Institute (INE) announced an Afro-descendant Characterisation Survey (ENCAFRO) to gather information about the regional Afrodescendant population. A questionnaire, based on self-identification, was drawn up in conjunction with the organisations and applied. It found that 8,415 people, or $4.7 \%$ of the regional population, identified themselves as Afro-descendant (INE 2014).

However, this demand to 'count the Afros' sought to go further and incorporate a question in the National Population Census, carried out by INE, which had included a question on indigenous identification since 1992. The organisations and their advisors, who included one of the authors of this paper, proposed several formulas that would be the least invasive possible for the Abbreviated National Census to be implemented in 2017. The simplest of these was to modify the title of the existing question about indigenous identification and add Afro-descendants as one of the categories. A similar modification had been made in the 2012 Census to incorporate the Diaguita people (recognised in 2006) so it was hoped this would not be too difficult. A meeting was held with INE's director, Ximena Clark, who refused to incorporate the question and, in the face of pressure from a prominent lawyer specialising in indigenous rights and the support offered by the Latin American and Caribbean Demographic Centre 
(CELADE), suggested that, as there was insufficient time to introduce the modification, Afro-descendants could mark the 'Others' category in the indigenous question and then add a comment indicating that they were Afro-descendants. Despite the refusal and frustration, the organisations decided to work with this option, mounting a campaign taking this act of discrimination as its rallying call.

This was just one of the many responses from different spheres of the state categorically refusing inclusion in the Census. In a demonstration of structural racism and denial of the existence of Afro-descendants, the President's office informed Afro-descendants that their demands would be considered in the next migration law while the Supreme Court indicated that they could not be included in the Census because they had not yet been legally recognised and could not, therefore, be considered subjects of law.

The dispute about Afro-descendant legitimacy and positioning not only had an institutional expression, but was also seen among indigenous people. This was illustrated by a conversation with an Aymara intellectual as part of the research for this paper. When asked who has rights over the Indigenous Law and, by extension, ILO Convention 169, his answer was categorical: indigenous people, who had fought for recognition and, in case of the Aymara, had a culture with a history of more than 5,000 years in the territory and their own recognisable language in an implicit comparison with Afrodescendants, who were arrivals to Chile and do not have their own language. It should be noted that many of the officials implementing projects arising from the Indigenous Law are Aymara and come from indigenous organisations that actively participated in discussion of this law. The Aymara intellectual also cited a strategic difficulty for the inclusion of Afro-descendants in policies related to the Indigenous Law and Convention 169 in that, in the long run, it would mean 'distributing the cake among more mouths'. There were, indeed, a number of disputes and tensions related to resources, who has a right and who is more 'original' as a people. This is an issue studied by Paine (1999) with reference to land disputes in Australia.

An essentialist vision is also brought into play opportunistically to differentiate one group from another that has historically been at a disadvantage. This condition of oppression and domination, although shared by indigenous people, reflects unwillingness of the part of the Aymara and other indigenous peoples to share or lose the spaces of power they have achieved and to which they see the emergence of Afro-descendants as a challenge.

This attitude could be observed in two indigenous consultation processes that took place in compliance with Convention 169 about the proposed creation of a Ministry of Indigenous Peoples and a Ministry of Culture. ${ }^{6}$ They coincided with the Afro-descendant movement's quest for legitimacy and they argued that Afro-descendants, as a tribal people, should be consulted along with indigenous peoples. This political strategy was strongly 
influenced by experiences in other Latin American countries such as Ecuador and Mexico.

The first consultation process referring to the creation of a Ministry of Indigenous Peoples was headed by the Ministry of Social Development. From the beginning, Afro-descendants were refused participation. However, in the second process about the creation of a Ministry of Culture (finally given the name of Ministry of Cultures, the Arts and Heritage), there was a positive response to Afro-descendants' participation and a space was created for them to participate as 'guests'. Aymara organisations and leaders, as well as other indigenous people in the region, objected and the conflicts this caused were expressed in the closing event of the consultation process which was attended by both indigenous and Afro-descendant representatives. An Afrodescendant leader explained that the Aymara leaders attributed their objections to Afro-descendants' lack of a territory and the status of a people. They were supported by other indigenous leaders of Mapuche and Rapanui origin and, as the Afro-descendant activist recounted, the tension was such that it led to verbal aggression and violent behaviour.

A similar situation of conflict was observed in Santiago in a meeting, attended by representatives of indigenous peoples and an Afro-descendant leader, to discuss the consultation process that was concluding. Some indigenous leaders expressed annoyance at the inclusion of the Afrodescendants who, in their view, had hindered the process and caused conflicts between the different indigenous peoples.

The participation of Afro-descendants in these consultation processes revealed the difficulties of accepting this identity, in addition to indigenous identities, in a process involving the country's cultural diversity and the right to recognition. This raises the question of what is at stake in this discussion: struggles for spaces of power, resources, recognition or protagonism in the politics of difference or the role that Convention 169 itself has in the demands and claims of indigenous peoples in Chile. Regardless of the justice or otherwise of the Afro-descendants' demands, the mere fact that they can be considered indigenous or in a structural situation similar to indigenous peoples is itself an obstacle to their recognition, although that has been the strategy adopted by most Latin American countries (Wade 2005).

Afro-descendant leaders have not argued that they want to be considered indigenous, but that the conditions of exclusion to which they have historically been subjected reflect a framework of inter-ethnic relations similar to those affecting indigenous peoples and that they have the backing of international law protecting the peoples that existed throughout the world before the constitution of today's nation states and were affected by the expansion of the West. Other arguments are also used to delegitimise Afro-descendant demands, related to the great miscegenation to which they have been subjected or the many years in which they were invisible and did not even 
self-identify as Afro-descendant. In this sense, the Afro-descendant process bears many similarities to other ethnogenetic processes (Campos 2014).

\section{Municipal office for Afro-descendant affairs: local positioning}

Although some steps have been taken, local and regional public policies for Afro-descendants are incipient and limited and have not permeated upwards to the national level. Since 2003, funding has been awarded for projects in areas that include culture and identity, economic development, healthcare and education programmes, programmes for women, the transfer of land and the construction of housing as well as the Characterisation Survey mentioned above. In addition, working groups have been established with the participation of representatives of the regional government, the municipal government and Afro-descendant organisations to coordinate the different regional government initiatives. Perhaps one of the most relevant achievements was the municipal government's creation of an Office for Afro-descendant Affairs in 2010. This marked a milestone in that it constituted a recognition by the municipal government of the Afro-descendants' existence, reinforcing the ongoing political process.

In Chile, it is common for instances to be created at the municipal level to address specific problems. They are usually referred to 'offices' and do have a physical space within the municipal government's premises, but consist principally in a work team with a budget and specific functions. The Arica municipal government has three offices related to cultural diversity: the Office for Afro-descendant Affairs, the Office for Indigenous Development and the Office for Diversity and Migrants. Their function is, in general terms, to serve a specific population and support coordination within the municipal government and with other government institutions.

The oldest of these offices, the Office for Indigenous Development, is responsible for coordinating indigenous and, particularly, Aymara matters and ensuring their visibility within the municipal government. Its activities seek to support indigenous organisations and individuals in different areas. The Municipal Office for Diversity and Migrants (MINTRAS) was established in 2015 to address local issues that fell outside the scope of the other two offices.

Until a few months ago, the Office for Afro-descendant Affairs shared its premises with the Office for Indigenous Development, occupying a small space, with a group of five to six people working at adjoining desks. Its marginal position within the municipal structure was reflected in the lack of a minimum level of comfort and privacy for attending people. Despite having shared the same physical space, the two offices work independently. Several of the officials are Aymara or Afro-descendant leaders. Given their dual role as leaders and municipal officials, they have a certain level of autonomy within 
the municipal apparatus, giving them room for negotiation that reflects their positioning and that of other players at the local and national levels regarding indigenous and Afro-descendant affairs.

Afro-descendant organisations also obtained the appointment of an official in the municipal government of the town of Azapa, one of the areas with the most Afro-descendant inhabitants. This official is the leader of Lumbanga, one of the longest-standing Afro-descendant organisations. As in the case of other Afro-descendant officials, this dual position as leader and official has caused internal conflicts such as disputes for leadership and about roles in decision-making and the management of relations with external advisers or agents.

One of these Afro-descendant leaders-officials asked the Arica municipal government to hold one the intercultural skills courses that we offered as part of our collaborative research work. We had given this course in other indigenous contexts in Chile but, in Arica, faced the challenge of including Afrodescendants and migrants. As in previous courses, we incorporated local partners in the design and implementation of the workshop. This was essential for the sake of the legitimacy of the proposed activities and the inclusion of the various participants. The course was attended by 30 public officials and representatives of civil society, an important number of whom had links to programmes for the indigenous population (ten participants), programmes within the framework of municipal actions for Afro-descendants (eight participants) and the rest to programmes run by the municipal government or civil organisations.

The main issues addressed were racism, discrimination, stereotypes of the other and the role of public officials in reproducing difference through their official actions. One of the activities consisted of simulating a television interview with two important representatives of the Aymara and Afro-descendant peoples. It referred in personal terms to the discrimination they had experienced during their lives and how they rebelled and took identitary political action. What was interesting about this exercise was the conclusion that, regardless of whether it is related to indigenous or Afro-descendant origin and the different ways it may be expressed, discrimination is, in practice, the same. This prompted deep reflection on the part of the participants.

Other exercises took specific situations from the region involving intercultural relations, drawn from real local news or everyday state practices which the participants could recognise. In the case of news, newspaper clippings about 'situations of discrimination' were used, including an incident involving a foreign Afro-descendant football player and the case of two indigenous migrants who were unjustly accused of an illegal act. For state practices, the examples used included differences in treatment under immigration policy depending on the person who wants to enter Chile from Peru and the attention received at public primary healthcare centres. The 
preparation and staging of each of the exercises fostered group reflection about differences in forms of discrimination depending on a person's origin and the important role that public officials play in this process.

One of the conclusions of the workshop was that 'differentiated discrimination' exists and permeates state practices but that officials can transform these practices. Migrants, especially indigenous migrants, emerged as the group suffering the most discrimination and, in line with the experience in indigenous consultation processes, a certain rivalry was apparent between the Aymara and Afro-descendants.

\section{The road to political recognition}

When Afro-descendant demands became visible, various associations were formed, which then multiplied over the years, increasing the complexity of the demands. In 2003, only one organisation existed but, by 2017, there were more than 40. The first to be formed was Oro Negro (Black Gold), an NGO whose mission was to instal the Afro-descendant issue in regional discourse and to bring together a group of sectors that would later go on to form their own associations (Campos 2017). This process of organisational multiplication, but also of factionalism, was the result of the organisations' quest for specificity in their objectives. Their proliferation also reflected the singularity of the subject demanding recognition, leading to the creation of associations of Afro-descendant women and senior citizens and associations around a particular cultural aspect such as Afro-descendant dance, music, or food or related to a place of origin, whether rural or urban. The latter also implied specific demands such as those related to the traditional territory in the Azapa Valley or the traditional occupation of neighbourhoods in the city of Arica (urban Afro-descendants). Other more recent associations have been formed to demand housing subsidies or to strengthen Afro-descendant religious festivities. Over time, it has become clear that the movement has been most successful when agreement has been reached on priority objectives. This has strengthened the institutionalisation of demands through the Office for Afro-descendant Affairs as well as links with the public apparatus and private organisations that can support these demands.

As the movement's organisation strengthened as from 2010, it began to feel a need to work with universities and academics who could contribute related scientific knowledge. At the end of 2012, Afro-descendant leaders, who were also linked to the municipal office, approached our team about possible support in the construction of genealogies to identify the main Afrodescendant family groups in Arica. In the initial conversations, it was agreed that, beyond genealogies, a sociocultural characterisation, based on an anthropological discourse, was required to provide scientific information about who these Afro-descendants demanding recognition were. 
The objectives of the research were scientific but it also sought to address the needs arising from the Afro-descendant movement's demand for recognition. This has enabled us, as researchers, to comply with the requirements that the scientific world imposes on our activities and, at the same time, be present in most of the instances in which the Afro-descendant issue has been addressed and have a direct influence on decision-making.

In almost seven years of work together with Afro-descendant organisations, we have been able to follow the movement's development and observe some changes with respect to its initial objectives. The most important of these changes was its shift from demanding recognition only at the local level to the position that recognition was only feasible if the movement became part of the struggles and demands of Afro-descendants around the region. It, therefore, strengthened its relations with Afro-Uruguayans, AfroPeruvians and Afro-Bolivians and became part of a broader discussion that would slowly come to include the situation of migrants. In this context, a key matter of debate within the organisations was the relation with the so-called Afro-migrants.

In this sense, the Afro-descendant movement of Arica, although starting out as markedly local in nature and distinguishing its demands from those of Afro-migrants, changed over the years as it came to understand that its demands were no different from those being raised in other countries like Peru, Argentina, Uruguay, Colombia, Ecuador and Mexico. The support it began to receive from intellectuals and activists in other countries prompted the internationalisation of local demands, leading the movement to wonder how recognition would affect the treatment of Afro-migrants in Chile. The recognition process coincided with a change in Chile's immigration policy which has become more restrictive, specifically as regards Afro-descendant migrants, who have been 'encouraged' to leave the country on humanitarian grounds. The question, therefore, is whether the new legal framework can bring about an improvement in the living conditions of migrants and recognition of their rights, particularly considering that the fight against racism and discrimination is a pillar of the Afro-descendant movement in Arica.

Finally, it is important to note that, in the 20 years since the irruption of the Arica Afro-descendants' demand for recognition, much has changed and it is surprising that, despite the discrimination and racism rooted in the pigmentocratic logic of the Chilean national state, Afro-descendants have finally achieved recognition. The regulation required to bring the law into full effect is still pending and work with the authorities is required to ensure the incorporation of a question about Afro-descendants in the 2022 National Census. Nonetheless, Arica and other sectors throughout Chile are becoming more sensitive to the Afro-descendant issue. The arrival of Afro-descendant migrants, while exposing the racist logic of both the state and civil society, has also increased familiarity with the presence of Afro-descendants. For now, 
projects specifically for Arica's Afro-descendants will continue to be tendered and will soon be extended to other parts of the country. In the Tarapacá Region, immediately south of the Arica y Parinacota Region, old Afrodescendant enclaves are increasing their visibility and, in Santiago, there are groups seeking to rescue the black identity of the city's La Chimba district. At least in Arica, Afro-descendant enterprises in areas such as gastronomy, crafts, music and dance will continue to flourish and this will undoubtedly put ongoing pressure on diversity policies in the region and the rest of the country.

\section{Conclusions}

The irruption of Afro-descendants on the national stage, manifested in the approval in 2019 of Law $N^{\circ} 21.151$, serves as a case study of the development of national and local public policy in response to a new diversity in a country that has traditionally favoured a homogeneous national project. It demonstrates the flaws of a single vision of society and, therefore, a policy that does not consider cultural diversity.

The struggles of Afro-descendants were preceded by those of Chile's indigenous peoples who, after centuries of being excluded and ignored, have achieved a space of power and recognition since the 1990s and the restoration of democracy. Over the years, indigenous or intercultural politics have gained in strength within the state, among indigenous peoples and in society in general. Meanwhile, Afro-descendants developed their own strategy, no longer in a context of denial of diversity, as was the case for indigenous peoples, but in an environment in which other diversities are recognised, albeit not necessarily willing to share the spaces of recognition they have achieved.

These disputes over spaces of power, resources and positioning on the public stage implied that Afro-descendant organisations strengthened their internal strategies on their legitimacy as a differentiated group. This opened the way to ethnogenetic processes, which have been promoted both internally by Afro-descendant leaders, by specific public institutions (such as cultural institutions and the municipal government) and by advisers and private organisations as well as through links with the Latin American Afrodescendant movement.

By using examples to analyse the irruption of Afro-descendants at the national, regional and local levels of the public institutional framework, this research was able to observe both the obstacles they encountered in the state apparatus and the spaces that opened the way to policies into which they were gradually incorporated. In turn, these openings in the institutional framework led to disputes with indigenous peoples for spaces of power and, even, rejection on the latter's part. 
It is clear that, for indigenous peoples, the mere idea of another actor demanding resources from the state makes it difficult for them to value a different cultural diversity and, initially, they resisted any possibility of Afrodescendant recognition. However, now that recognition has been achieved, the only alternative is to reach agreement on how to manage, together with the municipal, regional and national governments, those aspects related to their place in the formation of Arica and also of Chile. In this context, the situation of migrants could serve as a meeting point between the indigenous and Afro-descendant movements, insofar as they show sensitivity to migrants' demands and cease to view them as competitors for the scarce resources available for diversity policies.

To sum up, the question of diversity policies in Arica, viewed through the study of the emergence of Afro-descendants, can be seen as a situation in which various agents are striving for visibility on the regional stage, obliging different actors to participate in recognition politics. This has not necessarily been conducive to overcoming the contradictions generated by a nationalistic and homogenising model of understanding cultural differences, but does represent progress compared to the years of political and economic exclusion and invisibilisation of indigenous peoples, Afrodescendants and migrants.

The demands of Afro-descendant organisations and leaders have sensitised the region and, in particular, the Arica municipal district. This is reflected in public actions targeting this population that demonstrate not only that they have become a focus of public policy but also the ambivalence of policies which, on the one hand, recognise their presence and, on the other, insist on denial and their invisibilisation in Chile.

Finally, we would like to emphasise the importance of the collaborative research on which this paper is based. It provides an opportunity to get to know and participate in a political process from within and to obtain feedback for the progress and results of the research. But, even more importantly, it implies that the research has concrete significance for the actors/collaborators who participated and can contribute to their road to recognition.

\section{Notes}

1. The term Afro-descendant began to be used politically in 2000 following the Santiago preparatory meeting for the Durban Conference. In this same year, Chilean Afro-descendants also began to make their demands heard. Today, they claim recognition as Afro-descendants, Afro-Chileans, Afro-Ariqueños (after the name of the inhabitants of Arica) or even as negros (blacks) or morenos (browns). In Law $\mathrm{N}^{\circ} 21.151$, they are recognised as the Chilean Afro-descendant Tribal People.

2. The collaborative work with the municipal government was carried out under a verbal agreement between the municipal government and its office for Afro- 
descendants and the Centre for Intercultural and Indigenous Studies (CIIR), which is formed by three universities: Pontificia Universidad Católica de Chile, Universidad Academia de Humanismo Cristiano and Universidad Diego Portales. The Socio-Territorial Study was conducted with the Academia de Humanismo Cristiano, which subsequently joined CIIR.

3. For a more detailed analysis of the forms of implementation of indigenous policy, see De la Maza and Bolomey (2019).

4. According to the 2017 Census, $12.8 \%$ of Chile's population is indigenous. A total of nine indigenous peoples are recognised. In the north of Chile, they correspond to the Aymara and Quechua related to the Andean tradition.

5. According to the Chilean Immigration Department, in 2019 a total of 6,576 visas were issued to foreigners, mainly Venezuelans, Bolivians and Peruvians (https:// www.extranjeria.gob.cl/estadisticas-migratorias/). In terms of local public policies for migrants, Binational Transit Agreements facilitate the movement of Peruvians and Bolivians, especially in the city of Arica. They mostly work informally in conditions of vulnerability of rights. Public policies for the migrant population are very incipient and have been generated in response to particular local situations that have influenced national norms on the protection of rights. This was the case, for example, of the death of a baby who did not receive care at public health centres because the parents did not have formal migratory status.

6. For more details of these consultation processes, see De Cea and Peralta (2018).

\section{Disclosure statement}

No potential conflict of interest was reported by the authors.

\section{Funding}

This work was supported by the ANID/FONDECYT under Grant 1150876; ANID/ FONDAP under Grant 15110006; and European Union's Horizon 2020 research and innovation programme under the Marie Sklodowska-Curie GA under Grant 691004.

\section{References}

Assies, W., G. Van Der Haar, and A. Hoekema. 2002. "Los pueblos indígenas y la reforma del Estado en América Latina." Papeles de población 8 (31): 95-115.

Aylwin, J. 2014. "Los Derechos de los Pueblos Indígenas en América Latina: Avances jurídicos y brechas de implementación." In Derechos Humanos de los Grupos Vulnerables. Manual, edited by J. Felipe Beltrao, J. C. M. De Brito Filho, I. Gómez, E. Pajares, F. Paredes, and Y. Zúñiga, 275-300. Coordinators. Barcelona: Red de Derechos Humanos y Educación Superior.

Báez, C. 2010. Lumbanga. Memorias Orales de la Cultura Afrochilena. Santiago: Fondo de Cultura: Libro y Lectura.

Boccara, G., and P. Bolados. 2010. "¿Qué es el multiculturalismo? La nueva cuestión étnica en el Chile neoliberal." Revista de Indias 70 (250): 651-690. doi:10.3989/ revindias.2010.021. 
Campos, L. 2014. "El reconocimiento de nuevas identidades: Como enfrentar la etnogénesis desde la academia." In Pueblos Indígena, Estados nacionales y fronteras, edited by H. Trinchero, L. Campos, and S. Valverde, 219-245. Buenos Aires: FILO-UBA-CLACSO.

Campos, L. 2017. "Los negros no cuentan. Acerca de las demandas de reconocimiento de los Afro-descendientes en Chile y la exclusión pigmentocrática." Antropologías Del Sur 8: 15-31.

Chiarello, L., ed. 2013. "Las políticas públicas sobre migraciones y la sociedad civil en América Latina." Los casos de Bolivia, Chile, Paraguay y Perú, New York: Scalabrini International Migration Network.

Citrin, J., M. Levy, and M. Wright. 2014. "Multicultural Policy and Political Support in European Democracies." Comparative Political Studies 47 (11): 1531-1557. doi:10.1177/0010414013512604.

Constable, N. 2014. Born Out of Place. Migrant Mothers and the Politics of International Labor. California: University of California Press.

De Cea, M., and C. Peralta. 2018. "Implementación de la consulta indígena por el estado chileno: El caso del Ministerio de Desarrollo Social y del Consejo Nacional de la Cultura y las Artes." Culturales 6: e341.

De la Maza, F., and C. Bolomey. January 2019."Persistence and Changes in State Dependence in a Mapuche Indigenous Territory, Chile." Critique of Anthropology. doi:10.1177/0308275X18821178.

Duconge, G., and M. Guizardi. 2014. “Diásporas, etnicidad y etnogénesis: De las reflexiones teóricas a los estudios de caso sobre las comunidades afrodescendientes en América Latina." Papeles de trabajo 28: 95-119.

Echeverri-Pineda, C. 2018. "Reconocimiento constitucional para Afro-descendants en la región andina: Movilización social y cambio constitucional." Latin American and Caribbean Ethnic Studies 13 (1): 47-71. doi:10.1080/17442222.2018.1413969.

García, R., and G. Patricia. 2014. “Economía, migración y política migratoria en Sudamérica: Avances y desaíos." Migración y desarrollo 12 (23): 69-97.

Giraudo, L., ed. 2007. Ciudadanía y derechos indígenas en América Latina: Poblaciones, estados $y$ orden internacional. Madrid: Centro de Estudios Políticos y Constitucionales.

Gozdecka, D., S. Ercan, and M. Kmak. 2014. "From Multiculturalism to Post-multiculturalism: Trends and Paradoxes." Journal of Sociology 50 (1): 51-64. doi:10.1177/1440783314522191.

Guizardi, M., C. Pérez, I. Martínez, and D. Jordán. 2015. “Normativa legal de la migración en Chile: Marcos y definiciones jurídicas aplicables a la Región de Arica y Parinacota." In Migración internacional en Arica y Parinacota: Panoramas y tendencias de una región fronteriza, edited by J. Vicuña and T. Rojas, 71-86. Santiago de Chile: Servicio Jesuita a Migrantes.

Holmes, S. 2013. Fresh Fruit, Broken Bodies. Migrant Farmworkers in the United States. California: University California Press.

INE. 2014. Primera Encuesta de Caracterización de la Población Afro-descendant de la Región de Arica y Parinacota 2013. Santiago de Chile: Instituto Nacional de Estadísticas.

Kowal, E. 2008. "The Politics of the Gap: Indigenous Australians, Liberal Multiculturalism, and the End of the Self-Determination Era." American Anthropologist 110 (3): 338-348. doi:10.1111/j.1548-1433.2008.00043.x.

Kymlicka, W. 1995. Multicultural Citizenship: A Liberal Theory of Minority Rights. Oxford: Clarendon. 
Kymlicka, W. 2011. "Multicultural Citizenship within Multination States." Ethnicities 11 (3): 281-302. doi:10.1177/1468796811407813.

Lipschutz, A. 1944. El indoamericanismo y el problema racial en las Américas. Santiago: Nascimiento.

Maaka, R., and A. Fleras. 2005. The Politics of Indigeneity. Challenging the State in Canada and Aotearoa New Zealand. New Zealand: University of Otago Press.

Paine, R. 1999. "Aboriginality Multiculturalism, and Liberal Rights Philosophy." Ethnos 64 (3-4): 325-349. doi:10.1080/00141844.1999.9981607.

Postero, N. 2007. Now We are Citizens. Indigenous Politics in Postmulticultural Bolivia. Stanford: Stanford University Press.

Pozo, G. 2014. "¿Cómo decolonizar el saber? El problema del concepto de interculturalidad. Reflexiones para el caso." Polis Revista Latinoamericana 13 (38): 205-224.

Restrepo, E. 2013. "Etnización de la negridad: La invención de las "comunidades negras" como grupo étnico en Colombia." Genealogías de la negridad, Popayán, Cauca: Editorial Universidad del Cauca.

Rojas, N., and S. Bueno. 2014. "Redes de Inclusión: Estudio Estadístico de Las Condiciones Sociolaborales de Migrantes en Arica." In Migración y trabajo. Estudio y propuestas para la inclusión sociolaboral de migrantes en Arica, edited by N. Rojas and J. Vicuña, 56-100. Arica: Ciudadano Globla/OIM.

Salgado, M. 2013. Afrochileno: Una historia oculta. Arica: Ediciones Krom.

Sieder, R., ed. 2002. Multiculturalism in Latin America. Indigenous Rights, Diversity and Democracy. London: Institute of Latin American Studies.

Stavenhagen, R. 2002. "Indigenous Peoples and the State in Latin America: An Ongoing Debate." In In Multiculturalism in Latin America. Indigenous Rights, Diversity and Democracy, edited by R. Sieder, 22-44. London: Institute of Latin American Studies.

Taylor, C. 1993. El multiculturalismo y "la política del reconocimiento". México: Fondo de Cultura Económica.

Telles, E. 2014. Pigmentocracies: Ethnicity, Race and Color in Latin America. Chapel Hill: University of North Carolina Press.

Vertovec, S. 2001. "Políticas multiculturales y formas de ciudadanía en las ciudades europeas." Papeles de Población 7 (28): 221-241.

Vertovec, S. 2007. "Super-diversity and Its Implications." Ethnic and Racial Studies 30 (6): 1024-1054. doi:10.1080/01419870701599465.

Vertovec, S. 2010. "Towards Post-multiculturalism? Changing Communities, Conditions and Contexts of Diversity." Revue Internationale des Sciences Sociales, Revista Internacional de Ciencias Sociales LXI (61): 83-95.

Wade, P. 2005. "La Política Cultural de La Negritud en Latinoamérica y el Caribe." Guaraguao Revista de Cultura Latinoamericana CECAL, Año 9, no. 20.

Wright, S. 2011. "Studying Policy: Methods, Paradigms, Perspectives. Introduction." In Anthropology and the Analysis of Contemporary Power, edited by C. Shore, S. Wright, and D. Però, 27-31. United States: Berghahn Books. 